\title{
Melatonin Protective Role in Mouse Cauda Epipidymal Spermatozoa Damage Induced by Sodium Arsenite
}

\author{
Rol Protector de la Melatonina en el Daño de Espermatozoides de \\ Cauda Epididimaria en Ratón Producido por Arsenito de Sodio
}

Eduardo Bustos-Obregón,",*; Daniel Poblete ${ }^{* * * * * *}$; Roberto Catriao ${ }^{* * *}$; Mariano del Sol ${ }^{* * * * * *}$ \& Fábio Henrique Fernandes ${ }^{* * * * * *}$

BUSTOS-ObRegón, E.; POBLETE, D.; CATRIAO, R.; DEL SOL, M. \& FERNANDES, F. H. Melatonin protective role in mouse cauda epipidymal spermatozoa damage induced by sodium arsenite. Int. J. Morphol., 31(4):1251-1256, 2013.

SUMMARY: We evaluated the sperm parameters such as cauda epididymis weight, sperm count, sperm morphology and sperm DNA stability of adult CF-1 male mice treated daily (oral exposure) with the toxic sodium arsenite (As, $7.0 \mathrm{mg} / \mathrm{kg} / \mathrm{body}$ weight); Melatonin (Me, $10.0 \mathrm{mg} / \mathrm{kg} / \mathrm{bw}), \mathrm{Me}(10.0 \mathrm{mg} / \mathrm{kg} / \mathrm{bw})$ plus As ( $7.0 \mathrm{mg} / \mathrm{kg} / \mathrm{bw})$ and Negative Control ( $\mathrm{NaCl} 0.9 \%)$ to assess acute (8.3 days), chronic (33.2 days) and recovery of testicular damage (66.4 days). Arsenic decreases the number of sperm from chronic treatment (33.2 days) and this effect continued until 66.4 days of treatment. The toxic effect of As also altered the morphology of spermatozoa in all treatment periods when compared to the negative control group. However, Metalonin induced protective effects in periods of 33.2 and 66.4 days of treatment. Additionally, the stability of DNA was significantly affected by arsenic in all periods, but the chronic treatment (33.2 days) in the AsMe revealed increased stability compared to the group treated with arsenic only. Melatonin partially protects sperm toxicity caused by Arsenic, especially during periods of 33.2 and 66.4 days.

KEY WORDS: Mouse; Melatonin; Arsenic; Sperm; DNA stability.

\section{INTRODUCTION}

Chemical pollution and testicular function has been the subject of great concern in recent times, especially on the deleterious effects that many chemicals may have on reproduction (Bustos-Obregón \& Hartley, 2008). Among the ubiquitous compounds that occur naturally in the environment, arsenic is an important chemical toxic and carcinogenic (Patlolla \& Tchounwou, 2005).

The effect of sodium arsenite on the male reproductive system is not well defined, although there are some reports in which arsenic poisoning is associated with spermtoxicity, inhibition of testicular androgenesis and reduced testis weight and sex accessory organs in experimental animals (Jana et al., 2006).

The cellular mechanism of toxicity of arsenic includes generating reactive oxygen species (ROS) (De Vizcaya-Ruiz et al., 2009). Indeed, sperm are highly sensitive to the action of ROS due to the large amount of polyunsaturated fatty acids that compose their plasma membrane (Golden et al., 1999). Furthermore, due to sperm morphology, they have a very scarce cytoplasm, so that the amount of antioxidant molecules is limited (Garrido et al., 2004; Golden et al.).

For this reason, the application of exogenous antioxidants may have great significance in preventing oxidative damage induced in interstitial cells, germ cells or in the seminal plasma and sperm by exposure to metals such as arsenic (Koyuturk et al., 2006).

The antioxidant properties (Reiter et al., 2003) of exogenous melatonin (n-acetyl-5-methoxytryptamine), a main product secreted by the pineal gland in mammals (Von Gall et al., 2002) might have a protective effect on induced testicular toxicity by drugs (Patil \& Balaraman, 2009) or pesticide (Sarabia et al., 2009).

* Universidad de La Frontera, Temuco, Chile.

** University of Chile, Medical School, Santiago, Chile.

*** Veterinary School, Universidad Santo Tomás, Chile.

***** Centro de Investigación en Ciencias Biomédicas, Universidad Autónoma de Chile, Temuco, Chile.

${ }^{* * * * * *}$ São Paulo State University, Botucatu, Brasil. 
In this work, we aim to determine the effects of acute, chronic and recovery of testicular exposure to sodium arsenite in epididymal sperm and assess the use of melatonin as a protective agent and antioxidant.

\section{MATERIAL AND METHOD}

Three-month-old male mice (Mus musculus) strain CF-1, healthy and sexually mature, were obtained from the Faculty of Medicine, University of Chile. The animals were maintained in a room under controlled conditions of temperature $\left(22 \pm 2^{\circ} \mathrm{C}\right)$, and a $12 \mathrm{~h}$ light/dark cycle, with ad libitum access to commercial pellets and tap water.

Reproductive changes were studied as acute (8.3 days), chronic (33.2 days) and recovery of testicular damage (66.4 days) in 88 adult mice exposed every day to oral doses of Sodium Arsenite (As; 7.0 mg/kg/bw, Sigma Chemical Co., St. Louis, MO); Melatonin (Me; $10.0 \mathrm{mg} / \mathrm{kg} / \mathrm{bw}$, Arama Laboratorios SA, Santiago, Chile) (Gutelkin et al., 2001); Me (10.0 mg/kg/bw) plus As (7.0 mg/kg/bw), and Negative Control $(\mathrm{NaCl} 0.9 \%)$ delivered orally in a volume not greater than $0.05 \mathrm{~mL}$.

Before the beginning and after the end of treatment, all animals were weighted. Euthanasia was performed by cervical dislocation after anesthesia with ketamine (Laboratory Biosano SA, Santiago, Chile) according to the protocol of animal handling of the Bioethics Committee of the Faculty of Medicine, University of Chile.

\section{Sperm Parameters.}

Extraction, weighing and sperm count in epididymalcauda. After obtaining the cauda epididymis they were weighed. Then sperm suspension was obtained using the protocol by Fornés \& Bustos-Obregón (1994). Sperm were counted at $200 \mathrm{X}$ in a microscope, equipped to use Makler® chamber, adding a drop of sperm suspension by capillary and counting in duplicate the sperm present in the 100 squares of the camera, expressing this result as a million sperm/mg epididymis.

Sperm morphology analysis. From the sperm suspension obtained above it was obtained $200 \mu \mathrm{L}$ of sample. Additionally, $200 \mu \mathrm{L}$ of PBS was added and centrifuged at $2000 \mathrm{rpm}$ for 10 minutes. The resulting pellet was extracted and deposited on clean slides for performing a spread, allowed to dry at $37^{\circ} \mathrm{C}$ for $5 \mathrm{~min}$. Staining was performed using routine techniques (hematoxylin-eosin) and were then mounted with Eukitt ${ }^{\circledR}$. The analysis was performed by observing in optical microscopy 300 mouse sperm, evaluating their morphology as normal and abnormal categories, expressing the result as percentage normal sperm in all treated groups compared with controls (Vigil \& Bustos-Obregon, 1985).

DNA stability. Evaluation of the pattern of DNA denaturation in both experimental and control sperm was done fluorescence test of acridine orange (AO). This test is based on the properties of the fluorochrome acridine orange which emits red fluorescence by binding to denatured single-stranded DNA or green fluorescence when bound to double-stranded DNA (native). The sample preparation was performed according to the methodology used by Tejada et al. (1984).

Observation of the slides was performed using a Zeiss epifluorescence microscope M 0.1, calibrated to $100 \%$ of fluorescence emission at $524 \mathrm{~nm}$. 300 sperm were counted at 400X and results expressed in percentage of spermatozoa with stable DNA (green), in the experimental groups compared with the control.

Statistical Analysis. All results were expressed as mean \pm standard deviation. Statistical analysis of the results was performed using ANOVA test nonparametric KruskalWallis test and Dunn's multiple comparison, which allows us to compare and determine whether there are significant differences in the results between experimental groups in relation to a control group.

\section{RESULTS}

Sperm count downward trends present in the groups treated with As and AsMe treated groups compared to control groups at all tested intervals. Only 33.2 days decreased sperm counts significantly compared to control $(\mathrm{p}<0.001)$ and animals treated with As, while AsMe shows significant increase in sperm counts in this same range, relative to control $(\mathrm{p}<0.05)$ and As at 66.4 days only observed a significant decrease in sperm counts in animals treated with As and a no significant increase in the subject to AsMe, compared to the control (Table I).

Sperm morphology parameters revealed a significant decrease in normal sperm in animals treated with As intervals in acute, chronic and recovery to 66.4 days compared to their controls $(\mathrm{p}<0.05)$. AsMe treated animals, show a significant increase in the percentage of normal sperm with respect to control at 66.4 days of treatment (Table I). 
Table I. Values of sperm parameters of cauda epididymis from mice treated with arsenic, Melatonin, (AsMe) Melatonin plus Arsenic, and Negative Control (Neg. Control, $\mathrm{NaCl} \mathrm{0.9 \% )} \mathrm{at} \mathrm{different} \mathrm{times} \mathrm{after} \mathrm{treatment}$ (a.t.). Data were expressed as mean \pm standard deviation, different letters show significant difference between the groups.

\begin{tabular}{|c|c|c|c|c|}
\hline Time a.t. & $\begin{array}{c}\text { Cauda epididymis } \\
\text { Weight (g) }\end{array}$ & $\begin{array}{l}\text { Sperm count } \\
(10 \mathrm{e} 6 / \mathbf{m g})\end{array}$ & $\begin{array}{c}\text { Sperm } \\
\text { Morphology (\%) }\end{array}$ & $\begin{array}{c}\text { Sperm Stability } \\
\text { of DNA }(\%)\end{array}$ \\
\hline \multicolumn{5}{|l|}{8.3 days } \\
\hline Arsenic & $0.032 \pm 0.005 \mathrm{a}$ & $0.62 \pm 0.10^{\mathrm{a}}$ & $57.5 \pm 5.1^{\mathrm{b}}$ & $87.6 \pm 0.3 \mathrm{~b} * * *$ \\
\hline Melatonin & $0.035 \pm 0.004 \mathrm{a}$ & $0.67 \pm 0.15^{\mathrm{a}}$ & $74.8 \pm 5.2^{\mathrm{a}}$ & $90.2 \pm 0.2^{\mathrm{a}}$ \\
\hline AsMe & $0.030 \pm 0.005 \mathrm{a}$ & $0.55 \pm 0.10^{\mathrm{a}}$ & $70.7 \pm 10.2^{\mathrm{a}}$ & $89.1 \pm 0.3^{\mathrm{a}}$ \\
\hline Neg. Control & $0.037 \pm 0.004 a$ & $0.67 \pm 0.12^{\mathrm{a}}$ & $80.2 \pm 10.1^{\mathrm{a}}$ & $91.4 \pm 0.3^{\mathrm{a}}$ \\
\hline \multicolumn{5}{|l|}{33.2 days } \\
\hline Arsenic & $0.043 \pm 0.015 \mathrm{a}$ & $0.38 \pm 0.17^{\mathrm{b}}$ & $53.2 \pm 1.4^{\mathrm{b} * * *}$ & $51.2 \pm 1.2^{\mathrm{b}}$ \\
\hline Melatonin & $0.050 \pm 0.018 \mathrm{a}$ & $0.78 \pm 0.18 \mathrm{c}{ }^{*} * *$ & $74.1 \pm 3.2^{\mathrm{a}}$ & $92.5 \pm 0.8^{\mathrm{a}}$ \\
\hline AsMe & $0.055 \pm 0.020 \mathrm{a}$ & $0.64 \pm 0.12^{\mathrm{a}}$ & $81.2 \pm 5.8^{\mathrm{b}}$ & $62.4 \pm 0.9^{\mathrm{ab}} * * *$ \\
\hline Neg. Control & $0.042 \pm 0.002 \mathrm{a}$ & $0.68 \pm 0.05^{\mathrm{a}}$ & $88.3 \pm 6.2^{\mathrm{a}}$ & $93.1 \pm 0.8^{\mathrm{a}}$ \\
\hline \multicolumn{5}{|l|}{66.4 days } \\
\hline Arsenic & $0.042 \pm 0.012 \mathrm{a}$ & $0.37 \pm 0.10^{\mathrm{b}}$ & $62.5 \pm 2.4^{\mathrm{b} *} * *$ & $61.1 \pm 1.4^{\mathrm{b}}$ \\
\hline Melatonin & $0.048 \pm 0.012 \mathrm{a}$ & $0.42 \pm 0.12^{\mathrm{a}}$ & $75.3 \pm 2.3^{\mathrm{a}}$ & $90.5 \pm 4.1^{\mathrm{a}}$ \\
\hline AsMe & $0.051 \pm 0.012 \mathrm{a}$ & $0.61 \pm 0.17^{\mathrm{a}}$ & $68.4 \pm 4.9 \mathrm{a}^{\mathrm{b}}$ & $62.5 \pm 5.9^{\mathrm{a}}$ \\
\hline Neg. Control & $0.049 \pm 0.028 \mathrm{a}$ & $0.75 \pm 0.17^{\mathrm{a}}$ & $88.8 \pm 4.1^{\mathrm{a}}$ & $90.2 \pm 4.3^{\mathrm{a}}$ \\
\hline
\end{tabular}

$(\mathrm{p}<0.05, * * * \mathrm{p}<0.001)$.

DNA of sperm subjected to a thermal shock of $90^{\circ} \mathrm{C}$ has a percentage of denaturation that increases in animals treated with As compared to control groups whose values increase in a time-dependent, way with values significantly lower of sperm DNA stable in all exposure intervals compared to controls, and As ( $\mathrm{p}<0,05)$. At 8.3 days there was a significant decrease in DNA stability in the group treated with As, over the control $(\mathrm{p}<0.001)$ but no significant increase was observed in this parameter in the group treated at the same interval with AsMe relative to controls (Table I).

DNA stability is significantly increased in animals subjected to chronic AsMe with respect to the control ( $\mathrm{p}$ $<0.05)$ and the groups treated with As $(\mathrm{p}<0.001)$ (Table I). Cauda epididymis weight, showed no significant variations in the animals treated with respect to AsMe, As and Control groups, in any of the ranges tested: acute (8.3 days), chronic (33.2 days) or the recovery to 66.4 days (Table I).

\section{DISCUSSION}

During the last two decades, authors have reported the continuing decline in semen quality worldwide (Auger et al., 1995), involving environmental toxicants as primarily responsible for male infertility. Among the damage, the oxidative stress plays vital role in aetiopathology of testicular functions by mechanisms involving peroxidative damage to the cell membrane (Vernet et al., 2004).

In this work, the environmental toxic Sodium Arsenite (As) adverse effects on fertility in male CF-1 mice, which is characterized by the decrease in the cauda epididymal sperm count, as in the partial arrest of spermatogenesis, observed in the groups treated with As in all treatment intervals, being significant at 33.2 days (four cycles of spermatogenesis). In fact, the arsenic may cause effects on testicular fertility, as decreased testosterone levels (Jana et al., 2006; Saradha \& Mathur, 2006) and mature spermatozoa do not undergo spermiation and are phagocytosed by Sertoli cells (Holdcraft \& Braun, 2004) as this process is dependent on androgens.

We observed a decrease in the percentage of normal sperm in animals treated with sodium arsenite, significantly from 8.3 to 33.2 days, probably due to reduced testosterone levels (Jana et al.), whereas morphological differentiation, and the proper maintenance of ectoplasmic 
specialization, responsible for anchoring and formation of the sperm head to the Sertoli cell are dependent on the androgen levels (Anahara et al., 2006).

Indeed, significant increases in the production of sperm head and tail abnormalities in experimental animals are observed after exposure to sodium arsenite (Pant et al., 2004). This is mainly due to exposure to ROS (Rajesh Kumar et al., 2002) generated by As. It also induces a rapid decrease in mitochondrial membrane potential, altering the activity of mitochondrial enzymes, promoting dramatic morphological change and loss of the internal organization of this organelle (De Vizcaya-Ruiz et al.), thus affecting cell morphology. Sperm morphology has proved to be a useful tool to discriminate between fertile and infertile males (Guzick et al., 2001).

On the other hand, in the group treated with metalonin (AsMe) we observed reverse of the damage caused by sodium arsenite from 8.3 days decreasing the percentage of sperm with abnormalities (teratozoospermia). In fact, melatonin decreased the rate of abnormal sperm caused by ischemia-reperfusion in rats (Kurcer et al., 2010).

Sodium arsenite also causes a significant decrease of the percentage of spermatozoa with stable DNA in all exposure intervals, probably as a result of oxidative damage to nuclear constituents, in particular DNA (Rajesh Kumar et al.), mediated by reactive oxygen species (Kitchin \& Ahmad, 2003). This is an important aspect to note, because fertilization involves the interaction between the DNA of the sperm and the oocyte, and the completion of the process depends in part on the integrity of the sperm DNA.

DNA damage observed during exposure to arsenic is not directly related to it, as it is they are not covalently bound to DNA structure. Rather indirectly, inducing the reactive oxygen species, generating adducts, breaking of DNA chains and crosslinks, in addition to chromosomal aberrations (Halliwell, 2007).

Additionally, arsenic has been shown to generate DNA damage in human lymphocytes (Yáñez et al., 2003), DNA hypomethylation and hypermethylation so the decrease in the stability of DNA observed in this study may be associated with its ability to generate adducts on the DNA strand (Goetz \& Luch, 2008).

Meanwhile, melatonin showed a significant degree of protection of DNA in the range of chronic exposure, from 16.6 to 33.2 days, mainly due to its ability of scavenging the radical species, as noted in subsequent studies, which showed that melatonin is a dose-dependent protective agent against DNA oxidative damage (Zhao et al., 2008).

We observed no significant difference in cauda epididymal weight for all groups analyzed. In fact, to sodium arsenite also change the weight testis does not cauda epididymis of rats ( $5.5 \mathrm{mg}$ by 30 days) (Pal \& Chatterjee, 2005).

\section{CONCLUSION}

Arsenic decreases the number of sperm, altered the morphology of spermatozoa and stability of DNA, but melatonin partially protects sperm toxicity caused by Arsenic by its antioxidant effect improving sperm quality (thermal DNA stability and morphological alterations) especially during periods of 33.2 and 66.4 days.

BUSTOS-OBREGÓN, E.; POBLETE, D.; CATRIAO, R.; DEL SOL, M. \& FERNANDES, F. H. Rol protector de la melatonina en el daño de espermatozoides de cauda epididimaria en ratón producido por arsenito de sodio. Int. J. Morphol., 31(4):1251-1256, 2013.

RESUMEN: Se evaluaron los parámetros espermáticos como peso de la cola del epidídimo, conteo de espermatozoides, morfología de los espermatozoides y estabilidad del ADN de espermatozoides de ratones machos adultos CF-1 tratados diariamente (exposición oral) con el tóxico arsenito de sodio (As, 7,0 mg/kg/peso corporal), melatonina (Me, 10,0 mg/kg/pc, Me (10,0 mg/kg/pc) más As $(7,0 \mathrm{mg} / \mathrm{kg} / \mathrm{pc})$ y el Control Negativo $(\mathrm{NaCl} 0,9 \%)$ en evaluación aguda (8,3 días), crónica (33,2 días) y recuperación del daño testicular (66.4 días). El arsénico reduce el número de espermatozoides en el tratamiento crónico (33,2 días) y este efecto continuó hasta 66,4 días. El efecto tóxico de As también altero la morfología de los espermatozoides en todos los períodos de tratamiento cuando se compara con el grupo control negativo. Sin embargo, metalonina indujo efectos protectores en períodos de 33,2 y 66,4 días de tratamiento. La estabilidad del ADN se vio afectada significativamente por el arsénico en todos los periodos, pero en el tratamiento crónico (33,2 días) con AsMe se observa un aumento de la estabilidad em comparación com el grupo tratado con arsénico. Sin embargo, la melatonina protege parcialmente a los espermatozoides del daño causado por arsénico, especialmente durante los períodos de 33,2 y 66,4 días.

PALABRAS CLAVE: Ratón; Melatonina; Arsénico; Esperma; Estabilidad del ADN. 


\section{REFERENCES}

Anahara, R.; Toyama, Y.; Maekawa, M.; Kai, M.; Ishino, F.; Toshimori, K. \& Mori, C. Flutamide depresses expression of cortactin in the ectoplasmic specialization between the Sertoli cells and spermatids in the mouse testis. Food Chem. Toxicol., 44(7):1050-6, 2006.

Auger, J.; Kunstmann, J. M.; Czyglik, F. \& Jouannet, P. Decline in semen quality among fertile men in Paris during the past 20 years. N. Engl. J. Med., 332(5):281-5, 1995.

Bustos-Obregón, E. \& Hartley, B. R. Ecotoxicology and testicular damage (Environmental chemical pollution). A Review. Int. J. Morphol., 26(4):833-40, 2008.

De Vizcaya-Ruiz, A.; Barbier, O.; Ruiz-Ramos, R. \& Cebrian, M. E. Biomarkers of oxidative stress and damage in human populations exposed to arsenic. Mutat. Res., 674(1-2):85-92, 2009.

Fornés, M. W. \& Bustos-Obregón, E. Study of nuclear decondensation of the rat spermatozoa by reducing agents during epididymal transit. Andrologia, 26(2):87-92, 1994.

Garrido, N.; Meseguer, M.; Simon, C.; Pellicer, A. \& Remohi, J. Pro-oxidative and anti-oxidative imbalance in human semen and its relation with male fertility. Asian J. Androl., 6(1):5965, 2004.

Golden, A. L.; Moline, J. M. \& Bar-Chama, N. Male reproduction and environmental and occupational exposures: a review of epidemiologic methods. Salud Publica Mex., 41(Suppl. 2):S93$105,1999$.

Goetz, M. E. \& Luch, A. Reactive species: a cell damaging rout assisting to chemical carcinogens. Cancer Lett., 266(1):73-83, 2008.

Gultekin, F.; Delibas, N.; Yasar, S. \& Kilinc, I. In vivo changes in antioxidant systems and protective role of melatonin and a combination of vitamin $\mathrm{C}$ and vitamin $\mathrm{E}$ on oxidative damage in erythrocytes induced by chlorpyrifos-ethyl in rats. Arch. Toxicol., 75(2):88-96, 2001.

Guzick, D. S.; Overstreet, J. W.; Factor-Litvak, P.; Brazil, C. K.; Nakajima, S. T.; Coutifaris, C.; Carson, S. A.; Cisneros, P.; Steinkampf, M. P.; Hill, J. A.; Xu, D.; Vogel, D. L. \& National Cooperative Reproductive Medicine Network. Sperm morphology, motility, and concentration in fertile and infertile men. N. Engl. J. Med., 345(19):1388-93, 2001.

Halliwell, B. Oxidative stress and cancer: have we moved forward? Biochem. J., 401(1):1-11, 2007.

Holdcraft, R. W. \& Braun, R. E. Androgen receptor function is required in Sertoli cells for the terminal differentiation of haploid spermatids. Development, 131(2):459-67, 2004.

Jana, K.; Jana, S. \& Samanta, P. K. Effects of chronic exposure to sodium arsenite on hypothalamo-pituitary-testicular activities in adult rats: possible an estrogenic mode of action. Reprod. Biol. Endocrinol., 4:9, 2006.

Kitchin, K. T. \& Ahmad, S. Oxidative stress as a possible mode of action for arsenic carcinogenesis. Toxicol. Lett., 137(1-2):313, 2003.

Koyuturk, M.; Yanardag, R.; Bolkent, S. \& Tunali, S. Influence of combined antioxidants against cadmium induced testicular damage. Environ. Toxicol. Pharmacol., 21(3):235-40, 2006.

Kurcer, Z.; Hekimoglu, A.; Aral, F.; Baba, F. \& Sahna, E. Effect of melatonin on epididymal sperm quality after testicular ischemia/reperfusion in rats. Fertil. Steril., 93(5):1545-9, 2010.

Pal, S. \& Chatterjee, A. K. Prospective protective role of melatonin against arsenic-induced metabolic toxicity in Wistar rats. Toxicology, 208(1):25-33, 2005.

Pant, N.; Murthy, R. C. \& Srivastava, S. P. Male reproductive toxicity of sodium arsenite in mice. Hum. Exp. Toxicol., 23(8):399-403, 2004.

Patil, L. \& Balaraman, R. Effect of melatonin on doxorubicin induced testicular damage in rats. Int. J. PharmTech Res., 1(3):879-4, 2009.

Patlolla, A. K. \& Tchounwou, P. B. Serum acetyl cholinesterase as a biomarker of arsenic induced neurotoxicity in sprague-dawley rats. Int. J. Environ. Res. Public Health, 2(1):80-3, 2005.

Rajesh Kumar, T.; Doreswamy, K.; Shrilatha, B. \& Muralidhara. Oxidative stress associated DNA damage in testis of mice: induction of abnormal sperms and effects on fertility. Mutat. Res., 513(1-2):103-11, 2002.

Reiter, R. J.; Tan, D. X.; Mayo, J. C.; Sainz, R. M.; Leon, J. \& Czarnocki, Z. Melatonin as an antioxidant: biochemical mechanisms and pathophysiological implications in humans. Acta Biochim. Pol., 50(4):1129-46, 2003.

Sarabia, L.; Maurer, I. \& Bustos-Obregón, E. Melatonin prevents damage elicited by the organophosphorous pesticide diazinon on mouse sperm DNA. Ecotoxicol. Environ. Saf., 72(2):663$8,2009$.

Saradha, B. \& Mathur, P. P. Effect of environmental contaminants on male reproduction. Environ. Toxicol. Pharmacol., 21(1):3441, 2006.

Tejada, R. I.; Mitchell, J. C.; Norman, A.; Marik, J. J. \& Friedman, 
BUSTOS-OBREgóN, E.; POBLETE, D.; CATRIAO, R.; DEL SOL, M. \& FERNANDES, F. H. Melatonin protective role in mouse cauda epipidymal spermatozoa damage induced by sodium arsenite. Int. J. Morphol., 31(4):1251-1256, 2013.

S. A test for the practical evaluation of male fertility by acridine orange (AO) fluorescence. Fertil. Steril., 42(1):87-91, 1984.

Vigil, P. \& Bustos-Obregon, E. Alkylating agents and mouse spermatogenesis: effects of a single dose of cyclophosphamide. Andrologia, 17(3):276-82, 1985.

Vernet, P.; Aitken, R. J. \& Drevet, J. R. Antioxidant strategies in the epididymis. Mol. Cell Endocrinol., 216(1-2):31-9, 2004.

von Gall, C.; Stehle, J. H. \& Weaver, D. R. Mammalian melatonin receptors: molecular biology and signal transduction. Cell Tissue Res., 309(1):151-62, 2002.

Yáñez, L.; García-Nieto, E.; Rojas, E.; Carrizales, L.; Mejía, J.; Calderón, J.; Razo, I. \& Díaz-Barriga, F. DNA damage in blood cells from children exposed to arsenic and lead in a mining area. Environ. Res., 93(3):231-40, 2003.

Zhao, F.; Liu, Z. Q. \& Wu, D. Antioxidative effect of melatonin on DNA and erythrocytes against free-radical-induced oxidation. Chem. Phys. Lipids, 151(2):77-84, 2008.
Correspondence to:

Prof. Dr. Eduardo Bustos Obregón University of Chile Medical School P.O. Box 70061

Santiago

CHILE

Fax and Phone: 562-27237488

Email: ebustos@med.uchile.cl

Received: 01-06-2013

Accepted: 22-09-2013 